\title{
Nurses' perspective on health education in Diabetes Mellitus Care
}

\author{
Perspectiva de enfermeiros sobre educação para a saúde no cuidado com o Diabetes Mellitus
}

La perspectiva de enfermeros sobre la educación para la salud en el cuidado con la Diabetes Mellitus

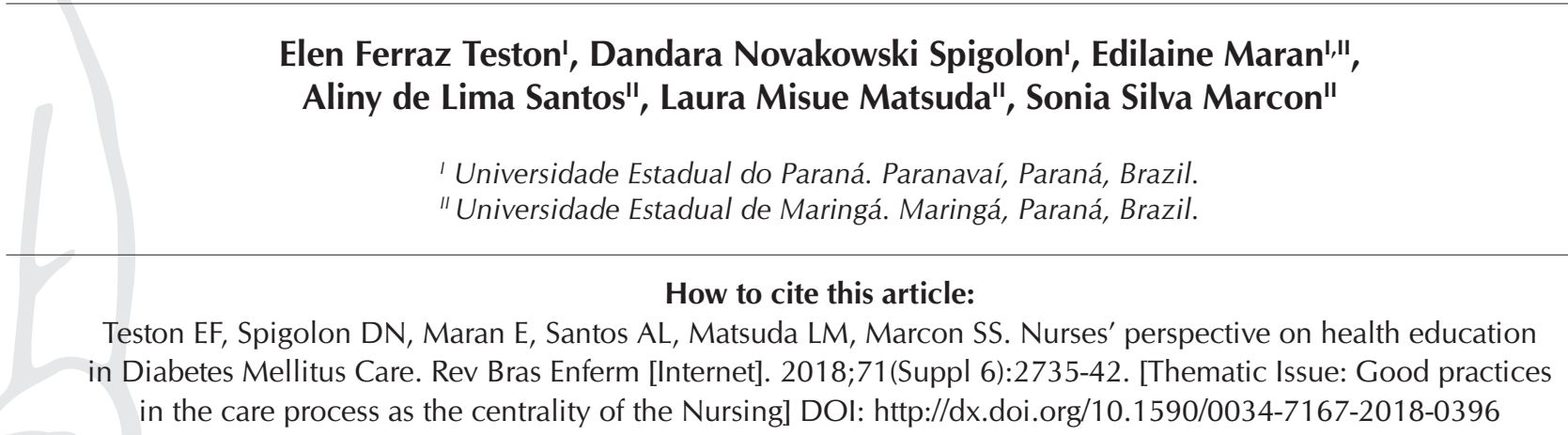

Submission: 06-05-2018

Approval: 06-16-2018

\begin{abstract}
Objective: to grasp the perspective of nurses on health education in the process of caring for people with Diabetes Mellitus in Primary Care. Method: a descriptive study of a qualitative nature carried out with 13 nurses from the Family Health Strategy in Southern Brazil. The data were collected in November and December of 2017, through recorded interviews, which were submitted to content analysis, thematic modality. Results: three categories emerged, which show from the perspective of nurses, the influence of structural and assistance characteristics in the development of educational actions; outcomes of these actions, and possibilities to increase their quality as central to the nursing action. Final considerations: there are still gaps in the structuring of public health policies, especially in the process of managing and caring for people with diabetes, which limits quantitatively and qualitatively the development of educational actions in Primary Care.
\end{abstract}

Descriptors: Primary Health Care; Nursing Care; Diabetes Mellitus; Health Education; Community Health Nursing.

\section{RESUMO}

Objetivo: apreender a perspectiva de enfermeiros sobre a educação para a saúde no processo de cuidado às pessoas com Diabetes Mellitus na Atenção Primária. Método: estudo descritivo, de natureza qualitativa, realizado junto a 13 enfermeiros da Estratégia Saúde da Família no Sul do Brasil. Os dados foram coletados em novembro e dezembro de 2017, por meio de entrevistas gravadas, que foram submetidas à análise de conteúdo, modalidade temática. Resultados: emergiram três categorias as quais mostram, na perspectiva de enfermeiros, a influência das características estruturais e assistenciais no desenvolvimento de ações educativas; os desfechos destas ações, e as possibilidades de ampliar a qualidade das mesmas enquanto centralidade do agir da Enfermagem. Considerações finais: ainda existem lacunas na estruturação das políticas públicas de saúde, em especial no processo de gestão e assistência a pessoas com diabetes, o que limita quantitativamente e qualitativamente o desenvolvimento de ações educativas na Atenção Primária.

Descritores: Atenção Primária à Saúde; Cuidados de Enfermagem; Diabetes Mellitus; Educação para a Saúde; Enfermagem em Saúde Comunitária.

\section{RESUMEN}

Objetivo: comprender la perspectiva de enfermeros sobre la educación para la salud en el proceso de cuidado a las personas con Diabetes Mellitus en la Atención Primaria. Método: estudio descriptivo, de naturaleza cualitativa, realizado junto a 13 enfermeros de la Estrategia Salud de la Familia en el Sur de Brasil. Los datos fueron recolectados en noviembre y diciembre de 2017, por medio de entrevistas grabadas, las cuales fueron sometidas al análisis de contenido, de modalidad temática. Resultados: surgieron tres categorías que muestran, en la perspectiva de enfermeros, la influencia de las características estructurales y asistenciales en el desarrollo de acciones educativas; los resultados de estas acciones y las posibilidades de ampliar la calidad de las mismas como centralidad del actuar de la Enfermería. Consideraciones finales: aún existen lagunas en 
la estructuración de las políticas públicas de salud, en especial en el proceso de gestión y asistencia a las personas con diabetes, lo que limita cuantitativamente y cualitativamente el desarrollo de acciones educativas en la Atención Primaria.

Descriptores: Atención Primaria de Salud; Atención de Enfermería; Diabetes Mellitus; Educación en Salud; Enfermería en Salud Comunitaria.

\section{CORRESPONDING AUTHORＥlen Ferraz Teston E-mail: elen-1208@hotmail.com}

\section{INTRODUCTION}

Chronic Noncommunicable Diseases, considered a public health problem, constituted $70 \%$ of the causes of death in the last eight years worldwide ${ }^{(1)}$. Among them, Diabetes Mellitus (DM) was the fourth most frequent, behind only cardiovascular diseases, neoplasia and respiratory diseases ${ }^{(1-2)}$. DM affects approximately 425 million people worldwide ${ }^{(3)}$, being relevant in the outcome of other comorbidities, besides being associated with the need for continuous care. The management of this disease is highly complex, since DM is influenced by diverse factors, such as genetic, as well as socio-cultural, environmental, food and life habits, also subject to regional differences ${ }^{(4)}$.

In this sense, it is essential that care for people affected by this chronic condition be planned and implemented, considering determinants and health factors, as well as individual needs and possibilities and the family context. It is necessary to construct spaces that contribute to the evolution of nursing care among people with diabetes, corroborating the principles of Primary Care, associated with the health policies in force, and that ensure care in a problem-solving, accessible and longitudinal manner, respecting hierarchical and political-administrative decentralization of services. In this way, it is possible for nurses to perform their praxis competently in order to promote comprehensive care ${ }^{(5)}$.

Despite the defense of these principles that guide daily practice in Primary Care, the care for individuals with DM presents a challenge to health services, which sometimes still concentrate their actions with an episodic, reactive and fragmented approach, which in general, does not respond to demands generated by this chronic condition. In this context, the Modelo de Atenção às Condições Crônicas (freely translated as Model of Attention to Chronic Conditions) favors the adoption of a new approach by proposing the coinsurance of subjects in care according to their capacity and use of community resources, with the objective of improving health services and recommending new care technologies( ${ }^{(6)}$.

The characteristics of this model include the provision of services according to population needs and in an integrated way between different points of attention, and with other sectors and health services, viewing at promoting self-care and valuing the principles of Unified Health System (SUS- Sistema Único de Saúde) ${ }^{(7)}$. Among the main aspects underlying this model is self-care supported, whose purpose is to support users in the process of (re)building their own health. Within the DM, we can use this strategy from the suspicion to the diagnosis, through interventions to a greater or lesser extent, depending on the state it is found ${ }^{(8)}$.

In this regard, Primary Health Care (PHC) occupies the center of Health Care Networks, as the main gateway and by allowing greater access of population to health services, consolidating initiatives of promotion, protection, recovery and rehabilitation, effectively operationalized by members from the Family Health Strategy $(\mathrm{FHS})^{(9)}$. In particular, for the nurse's role, educational actions transcend the joint construction of knowledge and orientation for self-care, raising new health needs, which evokes acquiescence in many care strategies, culminating in good practices in the process to care ${ }^{(10)}$.

In the present study, the concept of health education was adopted as the empowerment of individuals to control their own health determinants by encouraging the development of self-care for their own health-disease condition ${ }^{(11)}$. This concept is based on the principles of the Modelo de Atenção às Condições Crônicas, inasmuch as it places the individual as the center of care, the professional having the role of instrumentalizing it so that it becomes fit for self-care, monitoring and control of its pathology.

In health education, one of the main mechanisms to promote health in Primary Care in Brazil is that it recognizes that the health and disease process has a multidimensional character and the person with chronic illness is an active subject of education in search for autonomy in their care. In this sense, health education strategies constitute an important tool adopted by nursing with a view to a comprehensive care for the individual with diabetes in $\mathrm{PHC}^{(12)}$.

\section{OBJECTIVE}

To seize the perspective of nurses on health education in the process of caring for people with Diabetes Mellitus in Primary Care.

\section{METHOD}

\section{Ethical aspects}

The study was developed in accordance with the directives disciplined by the Conselho Nacional de Saúde (National Health Council), after authorization from the Municipal Health Office and approval by the Permanent Committee on Ethics in Research with Human Beings of the signatory institution. All the participants were clarified about the research and signed the Informed Consent Term. To guarantee confidentiality and anonymity, the representation of the names of the members was expressed by the letter $\mathrm{N}$, indicative of Nurse, followed by two Arabic numerals, the first referring to the order of interview and the second to the interviewee's age. Ex: (N1, 42 years).

\section{Theoretical and methodological framework}

For data systematization and treatment, we used the content analysis of Bardin ${ }^{(13)}$. The data analysis was based on the theoretical framework of the Modelo de Atenção às Condições Crônicas (freely translated as Model of Attention to Chronic Conditions) ${ }^{(6)}$. 


\section{Setting and type of study}

This is an exploratory study of a qualitative nature, carried out with nurses working at the FHS in a municipality in the South of Brazil, in which, at the time of data collection, a population of almost 82 thousand inhabitants. For the care of people with DM in the PHC, there were $24 \mathrm{FHS}$ teams allocated in 17 Basic Health Units (BHU).

\section{Methodological procedures}

For the development of the research, the BHU was initially contacted and the interview was scheduled according to the availability of the professionals. Next, the interview, data analysis was and full transcription of the perspective of nurses from the Family Health Strategy on the educational action in the care process for people with Diabetes Mellitus in Primary Care were carried out.

\section{Data source}

The informants in the study were 13 nurses who met the following inclusion criteria: working at the $\mathrm{FHS}$ for at least one year and being available for the interview up to three attempts to schedule. No exclusion criteria were established. All the contacts accepted to participate in the study and after inclusion, there were no withdrawals from participation. New inclusions occurred until additional information ceased to appear and data became repetitive, in addition to the fact that the research objective had already been reached.

\section{Collection and data organization}

The data were collected in November and December 2017, through semi-structured interviews, performed in a private space in the $\mathrm{BHU}$, by two researchers with experience in primary care and who had no link with the institutions surveyed. The interviews were guided by the following guiding question: Talk about the care process and health education actions developed with people with DM. They lasted an average of 20 minutes, were recorded and later transcribed in full.

\section{Data analysis}

All the interviews transcribed in full were subject to content analysis, thematic modality, following the steps of pre-analysis, material exploration, data processing and inference of the results. In the pre-analysis, the flutuante (an activity that aimed to generate initial impressions about the material to be analyzed (Bardin, 1977)) and individual reading of the interviews was carried out, followed by exploration of the material with a thorough and exhaustive reading of the printed content. Afterwards, the messages were codified by means of colors, and then the core meaning were apprehended, grouping them according to their similarities, emerging three thematic categories ${ }^{(8)}$ : "Structural and assistance characteristics influencing the development of educational actions among people with $\mathrm{DM}^{\prime}$; "Outcomes of health education actions developed with people with DM"; and "Perspectives of professionals to increase the quality of educational actions developed".

\section{RESULTS}

The 13 nurses participating in the study ranged in age ranging from 29 to 52 years (mean of 34.8 years), with training time between nine and 19 years (mean of 10.4 years), of which 12 were female. Nine had a postgraduate degree in Family Health/ Collective Health, with professional experience in Primary Care, ranging from one year and four months to 19 years (average of 8 years of work). The qualitative data analysis resulted in three categories that will be presented below.

\section{Structural and assistance characteristics influencing the development of educational actions among people with Diabetes Mellitus}

The participants emphasized that the availability or limitation of physical, physical and human resources directly interfere with the care of the individual with DM:

So, in fact, our physical structure today is very deficient, right here in the unit, we even share a room for two nurses, we attend patients at the same time, [...] it's a single room that attends all these patients. So the physical structure is quite limited. We have the capillary blood glucose device, with the strips, that in fact we don't always have the strips [...]. (N1, 42 years)

[...] ah, there is an office, a meeting room for educational activity, a large space outside the Unit for off-duty activities also and a well-suited structure. (N7, 35 years)

We have available here the glucometer, the strips, the descartex [container for the collection of health service waste and rigid, impermeable, sharp-proof material. It consists of: collector itself, cover, nozzle with over-cap, carrying straps and device for fixing it] to make available to those who use insulin at home, oral medication, [...] which is Metformin and Glibenclamide, syringe, strip, lancet. (N5, 35 years)

[...] checks of glucose, capillary blood glucose, there are the laboratory tests that are offered through medical appointment as needed, fasting blood glucose, postprandial, glycated hemoglobin. We have all the team, all the team attends the diabetic patient, not only the nurse, not only the doctor, there is the technician, the Community Health Agents in their home visits, they already do the counseling [...]. (N6, 38 years)

Regarding the actions developed with these individuals, the interviewees highlighted the modalities and approaches used to assist people with diabetes, emphasizing individual care, group meetings, home visits and risk stratification for demand organization:

[...] we meet with diabetic and hypertensive groups, with different counseling, various subjects, approaching their pathology, even their daily care [...]. (N1, 42 years)

So we hold some monthly meetings for hypertensive and diabetic people and there are micro area meetings, which are held also, blood glucose measurement, and from these meetings there is counseling and a lecture in the general meeting. (N6, 38 years)

[...] individual counseling is taken when these people come to medical or nursing care. (N2, 30 years)

Then we have individual care, which is where we start the risk stratification. The patient has to return according to the 
programmed, according to his risk, right. High risk has to come back every 3 months, then patient comes back, we do the counseling, evaluate the feet, and the medication, a capillary blood glucose. (N3, 30 years)

We carry out home visits, we do the stratification of cardiovascular and diabetes melittus risks, in the stratification we already do the counseling also, which are complemented by these lectures that we have biweekly here in the Unit. (N5, 35 years)

Specifically related to educational activities developed with this public, the nurses highlighted the lack of time and the overload of work as factors that hinder performance:

[...] lack of time, because I think if we had more time to work health education with population, I think we would achieve much more satisfactory results than what we have today. (N1, 42 years)

I have to meet the spontaneous demand, take care of all groups, hypertensive, diabetic, obese, smoking and so on. (N13, 36 years)

Here on my team, the time I have is short, because most of a team service is focused on the nurse. So, these are actions that I don't only need to do, right? But if you don't have a person who manages and commands, things don't work [...]. (N9, 34 years)

However, they use strategies such as the division of tasks among team members, the establishment of partnerships to overcome this difficulty:

[...] we have determined that each month, one of the community agents will be responsible for organizing the education activity [...] I think that delegating these responsibilities to the rest of the team can make it easier for everyone. This is how teamwork really works. To have the team walking along. (N8, 29 years)

[...] we count on the partnerships to develop these activities, partnership with colleges and vocational schools, several times nursing trainees are who perform for us. (N5, 35 years)

\section{Outcomes of health education actions developed with people with Diabetes Mellitus}

Nurses relate the low participation rate of individuals with DM in the health education activities offered, the way they are organized and offered, and the lack of knowledge about the patient's condition and the culture of the patients, who in general value the appropriate actions to biomedical model:

[...] I had to have time to work in the field with them [...] to have an informal conversation, it wasn't that thing you up front doing a lecture, then the patient feels closer, special, friend, the patient starts telling us how he/she does things and we can detect little things that help in the situation. (N7, 35 years)

Actions end up becoming not so attractive to the population due to the long term that we do between one and another, and sometimes with regard to the subject, that sometimes if you harp on the same string on the same theme, every month, people find themselves repetitive and don't attend the meeting. (N2, 30 years)

I believe that there is still a lack of active search, because there are still many diabetics who are in the area and don't know that they are diabetics, so in order to expand educational actions it is necessary to actively search for these patients who are in the area without knowing they are diabetics, often arrive, already at a very advanced stage, with some complications. (N12, 29 years)

It is difficult to bring these patients to the unit, it is very complicated because they are very resistant, they just want the prescription, you know, to be able to take the medication and only, they don't want to know about counseling [...]. (N1, 42 years)

[...] we have a bit of difficulty to work with them, because it touches the cultural part a little, what they eat, social, mess with them a bit, so we have a little difficulty to make them accept well the educational part, this part of feeding, this part of physical activity, [...]. (N3, 30 years)

Some nurses, however, reported positive results after the development of health education actions, through glycemic control and patients' reports regarding the change in habits:

[...] when we look at the glycemic indexes of patients who can keep the control, we see the actions results. And when patients who don't have this control can do this reduction and control the glycemic levels. (N2, 30 years)

[...] we closed a six-month group, and we saw patients we could remove medication, the ones who actually followed [...]. And also in the patients that we can do this control here in the unit, medical appointment, nursing appointment, examinations in the correct time, we also perceive a greater control of the capillary blood glucose and exams. (N3, 30 years)

While others reported failing to assess the impact of the actions undertaken:

[...] with the group in the way that we are doing today, we don't make any assessment [...]. (N9, 34 years)

\section{Perspectives of professionals to increase the quality of educational actions developed}

In the interviews, among the strategies listed by nurses as relevant, aiming to increase the quality of health education actions developed, are the offer of more information about the disease, symptoms and complications to the population, encouragement of the search for the basic unit for assistance, multiprofessional collaboration and support networks, as well as the active search in homes:

It is necessary to increase the disclosure of what diabetes can be causing when the person doesn't care, because it is a disease that often starts silent, many people will only find out when they are in a more advanced stage. Then, recovering is more difficult. [...] But increasing these strategies, 
spreading signs and symptoms, encouraging this population to be looking for unity, to make their periodic exams, to get these patients earlier. (N11, 34 years)

Oh, I have difficulty in convincing, so we used a lot of strategies, we had to bring patients under hemodialysis, to tell them they were diabetic. We have already brought pastoral team, with differentiated food. We've made different cakes here, just so they can see how good it is too, we brought the psychologist. [...] but I wanted to have more convincing power, to convince the patient that he/she needs to take care of his/her health [...]. (N3, 30 years)

So, I think the right thing should be like, I have a weekly schedule, every day of the week a technician comes out with a Community Health Agent, if I had enough strip for every home he/she goes, the person being diabetic or should do blood glucose test, because if you change an appointment schedule, we will ask for exams, do it on the street, in the square, because those who pass by are people who don't come in the Unit, but go to the square. (N9, 34 years)

However, some nurses emphasize the need for better preparation of the team members for the development of these actions:

[...] the team needs preparation, not only the nurse or the doctor. So I think this would help the team a lot. (N3, 30 years)

To improve the preparation of Community Health Agents also, so that in the home visits they, who are the direct contact, could make the counseling. It is necessary to train these professionals who are in the Ponta to start clarifying, because they are spending every day [...]. (N5, 35 years)

[...] training with the team as a whole, even the reception team has to have knowledge. My receptionist is 30 years old, who works here, so she has a reasonable knowledge, but there are lots of Units that are intern, who are younger people in the service. Sometimes a counseling given in the reception already helps, already collaborates, I think that this is also important to happen. (N8, 29 years)

In addition, they reinforce the need for the training offered by the regional health secretariat to focus on health promotion and prevention of complications:

[...] indeed, we are capable, once every six months we have training, but there we work more on the issue of flows, where to go, how to do stratification, we have many directed activities like this. And we don't have preventive activities, such as preventing diabetes, how to prevent obesity. (N7, 35 years)

[...] the training we have is focused on the stratification of hypertensive and diabetic people, but there are other things that we would need as well. The issue of the prevention of injuries or having the injury, what else can we do. (N10, 29 years)

\section{DISCUSSION}

PHC in Brazil, currently structured from the FHS, is the gateway to care for people with chronic diseases ${ }^{(14)}$. Although characterized as a coordinator of the Health Care Network, there are still difficulties imposed by the system itself for the development of promotion, prevention, treatment and rehabilitation actions. In order to be problem-solving and comprehensive, PHC actions depend on issues such as physical, material and human resources, and thus, the fragility in the supply of such inputs and resources has resulted in insipidity in the effectiveness of care, especially those who need it continuously and in the long term, such as people with $\mathrm{DM}^{(15-16)}$. Thus, seeking a perspective of nursing care for individuals with DM, considering the cultural, historical and political aspects necessary to guarantee comprehensive, equitable, accessible and quality care, depends on numerous questions, such as physical, material and human resources, and is characterized as one of the great challenges for public health ${ }^{(6,16)}$.

Participants emphasized that limiting available material, physical and human resources interferes with the adequate provision of health education actions to individuals with DM. Infrastructure is an important factor in the management process, when absent or insufficient, it triggers demotivation for professionals ${ }^{(17)}$. In addition, the absence or insufficient distribution of necessary inputs for the care of people with DM leads to incomplete treatment or abandonment, which can lead to inadequate control of the disease, its main complications and sequels $s^{(18)}$.

Among the activities developed by the team to attend the health education actions to the individual with DM, the interviewees highlighted group meetings with the development of health education activities, individual care, and risk stratification with the purpose of organizing the demand and home visits. The emphasis of the professionals in the group activities as an essential strategy to the prevention of the diseases and in the treatment of the DM was observed. When in a group, health education activities enable the sharing of similar histories and the exchange of experiences of health and illness, which in turn favors the implementation of behavioral changes, with consequent improvement of DM control and quality of life ${ }^{(19)}$.

It should be noted that although some have reported difficulties in planning, conducting and evaluating this process, health education actions should be given in every single individual and/or group service to these individuals. In this way, it is possible to optimize the individual's understanding of their co-responsibility for their own health.

However, the lack of time and the overload of tasks, pointed out by $\mathrm{N} 9$ and N13, are factors that hinder the development of health education activities. In spite of this, the work of Nursing at PHC is still often focused mainly on bureaucratic activities ${ }^{(20)}$. Thus, the need to reorganize the nurses' work process within the FHS is glimpsed, so as to recognize the importance of reviewing their duties at the PHC, to plan a care with a view to comprehensive and qualified care. Failure to comply with the systematization of care sometimes contributes to bureaucratization of work and production of decontextualized care, which is contrary to the guidelines of the $\mathrm{PHC}$, which provides for the provision of care based on the needs identified in the individual and family context.

For the development of health education activities, the strategies mentioned by the nurses were the establishment of 
partnerships with educational institutions, for example, and the assignment of responsibility for planning and implementing the actions to different team members, as well as the collaboration of others professionals such as nutritionist and psychologist. Support networks, such as pastoral care, were also cited as tools used to enhance and increase the impact of actions undertaken. In this sense, it is worth considering that the articulation of different areas presupposes an interaction of professionals who contribute to the care with different knowledge and experiences, which creates favorable spaces for supported self-care ${ }^{(6,21)}$.

Although there is a wide expansion of PHC throughout the country, guaranteeing access to health care services does not imply the fulfillment of health care. For this to occur, it is recommended that, in addition to promotion, prevention and treatment activities, the ways in which care practices are performed in health services is also fundamental for reaching the problem solving of care. In this perspective, multiprofessional teamwork, as well as the insertion of individual and family in the care, allows the construction of a cooperative work from multiple technical interventions and interaction of subjects with different professions, allowing an integrated care ${ }^{(6,21)}$.

However, although they emphasize the potential of the actions carried out, limitations have also been mentioned, since, as a rule, there is low population adherence, which makes them believe that this is due to the way in which they are carried out and offered. Considering the importance of these activities as a tool to encourage the active participation of individuals with diabetes in the planning, development and implementation of self-care actions ${ }^{(22)}$, it is worth highlighting the need for professionals to rethink the strategies used, and especially their approach - which is centered on the biomedical model.

The focus on the biomedical model still prevails in the conduct of the work and assistance developed in Primary Care, either by the lack of preparation of the professionals or by the very culture of the users who value this type of care. This perspective has already been found in other studies developed within the scope of PHC, which found that actions are often developed with the first purpose of accounting for the high demand for medical appointments and, for this reason, distance themselves from the care practices proposed in the Modelo de Atenção às Condições Crônicas (6,17,23-24).

A study that evaluated care for people with diabetes in the light of the Chronic Conditions model concluded that the implementation of this model of care is still a challenge for managers and professionals who are not prepared to break with the traditional model of care ${ }^{(23)}$.

The perspective of professionals and users about the evaluation of the control of DM in PHC led the authors of a study to conclude that the deficit in the planning of the activities carried out with people with arterial hypertension and/or Diabetes Mellitus and the lack of continuity in the offer of these activities under the PHC interfere with the implementation of actions, compromising the quality and purpose of its implementation ${ }^{(18)}$. The importance of a reflection by all the members of the team on the importance of these actions, integrate the monthly schedule of activities to be carried out and the need to have a planning of the same, the insertion of specific activities in the monthly schedule, with a view to how to offer them, the topics addressed and the methodology implemented, were flagged in this study.

It is noteworthy that some nurses reported positive results after the development of healthcare practices focused on health education actions. These results are observed in the evolution of the laboratory parameters and in the reports of patients on change of habits of life. This reinforces the result of a study on the competencies of health professionals, in which the interviewees recognized the importance of educational practices, considered strategic in the behavior changes for the control and prevention of diseases of people with $\mathrm{DM}^{(19)}$.

However, the verification of these benefits alone does not allow to evaluate the impact of educational actions, since it is limited to those individuals who seek the service, assiduously. In addition, some nurses (N3, N4, and N9) do not share this perception and even report total ignorance of the impact of the care provided. It is important to highlight that the evaluation of the implemented activities constitutes an essential item of the work process, since (re)evaluating these actions in a continuous way allows the professional to identify the gaps and to plan different actions throughout the process.

Two nurses (N5 and N8) reported that to improve the actions that are developed in the educational scope, it is necessary to qualify the different members of the team, while the nurses N7 and N10 emphasized the need of the training offered to have as main focus, the promotion of health and the prevention of injuries.

Meeting PHC's precepts in the actions developed is the main challenge to the FHS teams. Thus, in Permanent Education, an effective strategy in the training of the teams for a work that also values the promotion of health is envisaged. It is necessary to offer training capable of instigating the settlement of the multiprofessional team, interest and participation in the treatment, monitoring and evaluation of these individuals, as well as guaranteeing the Primary Care base and strengthening the Health Care Network ${ }^{(6,14,18,22)}$. In order to adapt the assistance offered to the Modelo de Atenção às Condições Crônicas, one must consider the complex and interdependent changes that are necessary in the structure of the service, in the culture of the users and in the training of professional $\mathbf{s}^{(6,25)}$.

Thus, throughout the history of Nursing, training of nursing professionals has been reinforced, learning to implement Nightingale's initial theories and later, Wanda Horta's theories centered on the relationship of nursing care among nurses, individuals, families, community and the basic human needs, which give subsidies to assistance that complies with SUS principles. Within this, the relation of the nurse in a crosscultural way makes the people receive a human service and of comprehensive form, under a holistic look. In short, it is perceived that since the antiquity, the nursing professional has dedicated and has as ethical and bioethical responsibility to promote, restore and maintain the health of the people, acting as the main tool in PHC, providing care to the person, family and to the community $(5,26)$.

It is necessary to consider that nursing experiences in its daily life a series of limits, for its sanitary and socio-political action, since many work in conditions of work overload, insufficient 
personal dimensioning, restricted salary remuneration and linear autonomy. However, it is also this challenging context that demands the development of strategic skills and tools that enable it to target a critical posture and actions that truly impact the lives of individuals, families and communities. Thus, health education practices are one of the most powerful tools for transforming care practice, in face of the current health context in the country. Such practice pertains to punctual, curative and reactive care, encompassing broad aspects such as social, cultural, economic and political issues ${ }^{(27)}$.

It is believed that health professionals, as facilitators of care practice who can promote sustained change in care, need the ability to assess the influence of culture on practice, team management over time, and systematized assistance. In this way, it will be possible to strengthen the pillars of Primary Care, and thus, to develop preventive and proactive care based on the population, and to favor patient centralization and support to self-management ${ }^{(25)}$.

\section{Study limitations}

The study's limitation is the possibility that its results are influenced by characteristics related to the training context and the performance of the participating professionals, and it is necessary to carry out studies in other scenarios.

\section{Contributions to Nursing, Health or Public Policy}

The study addresses the perspective of nurses on health education actions aimed at people with DM. Their results show that this issue is very problematic both in the daily services and in the nursing practice. It emphasizes the pertinence and relevance of these actions for comprehensive assistance to these people and consolidation of the precepts of the PHC. Good practice in the caring process, as the centrality of nursing, reaffirms the fundamental principles of respect for human rights that are inherent to the exercise of the profession.

\section{FINAL CONSIDERATIONS}

This study allowed to know the perspective of nurses from the Family Health Strategy on educational actions in care process for people with Diabetes Mellitus in Primary Care, highlighting the influence of the structural and assistance characteristics in the development of these actions, their outcomes and possibilities to expand the quality of the same as centrality of the Nursing action.

It is considered that there are still gaps in the structuring of public health policies, especially in the process of management and care for people with diabetes, which quantitatively and qualitatively limits the development of educational actions in Primary Care and the implementation of assistance to the individual with DM that meets the precepts of the PHC and the Modelo de Atenção às Condições Crônicas, weakening good practices in process of care. It is argued that health education is an effective and low-cost strategy. The nurses in study recognize their importance, but they resent support in their training and in the team, so that everyone can work in an integrated way, addressing pertinent, comprehensive and eminently preventive issues.

\section{REFERENCES}

1. Malta DC, Bernal RTI, Lima MG, Araújo SSC, Silva MMA, Freitas MIF, et al. Noncommunicable diseases and the use of health services: analysis of the National Health Survey in Brazil. Rev Saúde Pública[Internet]. 2017[cited 2018 Mar 12];51(Suppl-1):1-10. Available from: http://www.scielo.br/pdf/rsp/v51s1/0034-8910-rsp-S1518-87872017051000090.pdf

2. Marinho F, Passos VMA, França EB. Novo século, novos desafios: mudança no perfil da carga de doença no Brasil de 1990 a 2010. Epidemiol Serv Saúde[Internet]. 2016[cited 2018 Mar 12];25(4):713-24. Available from: http://www.scielo.br/pdf/ress/ v25n4/2237-9622-ress-25-04-00713.pdf

3. International Diabetes Federation-IDF. Atlas: 8th ed[Internet]. 2017[cited 2018 Mar 12]. Available from: http://www.diabetesatlas.org/

4. American Diabetes Association. Recommendations CP: standards of Medical Care in Diabetes-2016 abridged for primary care providers. Clin Diabetes[Internet]. 2016[cited 2018 Mar 14];34(1):3-21. Available from: http://clinical.diabetesjournals.org/lookup/ doi/10.2337/diaclin.34.1.3

5. Conselho Federal de Enfermagem-Cofen. Resolução Cofen No 0564/2017. Aprova o novo Código de Ética dos Profissionais de Enfermagem[Internet]. 2017[cited 2018 Mar 14]. Available from: http://www.cofen.gov.br/resolucao-cofen-no-5642017 59145.html

6. Mendes EV. As redes de atenção à saúde[Internet]. 2011[cited 2018 Mar 14];15(5):2297-305. Available from: http://www.scielo. $\mathrm{br} / \mathrm{pdf} / \mathrm{csc} / \mathrm{v} 15 \mathrm{n} 5 / \mathrm{v} 15 \mathrm{n} 5 \mathrm{a05} . \mathrm{pdf}$

7. Moysés ST, Silveira Filho AD, Moysés SJ, (Org.). A implantação do Modelo de Atenção às Condições Crônicas em Curitiba: resultados do Laboratório de Inovações sobre Atenção às Condições Crônicas na Atenção Primária em Saúde[Internet]. 2013 [cited 2018 Mar 14]. 390 p. Available from: http://apsredes.org/pdf/Modelo_Atencao_Curitiba.pdf

8. Fernandes LTB, Nóbrega VM, Silva MEA, Machado AN, Collet N. Supported self-care for children and adolescents with chronic disease and their families. Rev Bras Enferm[Internet]. 2017[cited 2018 Mar 14];70(6):1318-29. Available from: http://www.scielo. $\mathrm{br} / \mathrm{pdf} /$ reben/v70n6/0034-7167-reben-70-06-1318.pdf

9. Stein AT, Ferri CP. Inovação e avanços em atenção primária no Brasil: novos desafios. Rev Bras Med Fam Comun[Internet]. 2017[cited 2018 Apr 10];12(39):1-4. Available from: http://dx.doi.org/10.5712/rbmfc12(39)1586 
10. Ferreira NM, Cunha GT, Dias NG. O desafio da mudança: a transformação curricular de um Programa de Residência de Medicina de Família e Comunidade Rev Bras Med Fam Comun[Internet]. 2018[cited 2018 Apr 10];13(40):1-12. Available from: https://www. rbmfc.org.br/rbmfc/article/view/1600

11. Feio A, Oliveira CC. Confluências e divergências conceituais em educação em saúde. Saúde Soc[Internet]. 2015 [cited 2018 Apr 28];24(2):703-15. Available from: http://www.scielo.br/pdf/sausoc/v24n2/0104-1290-sausoc-24-02-00703.pdf

12. Vasconcelos MIO, Farias QLT, Nascimento FG, Cavalcante ASP, Mira QLM, Queiroz MVO. Educação em saúde na atenção básica: uma análise das ações com hipertensos. Rev APS[Internet]. 2017[cited 2018 Apr 20];20(2):253-62. Available from: https://aps.ufjf. emnuvens.com.br/aps/article/view/2927

13. Bardin L. Análise de conteúdo. Lisboa: Edições 70, 2011.

14. Sisnando LG, Sousa NDL, Fabricio NP, Brito LSA, Rebouças VCF, Alencar AMPG. Nurses' care process to users with diabetes in primary health care. Rev Enferm UFPE[Internet]. 2016[cited 2018 May 10];10(3):1094-101. Available from: https://periodicos. ufpe.br/revistas/revistaenfermagem/article/view/11063

15. Oliveira MM, Pinto IC, Cruz VD, Coimbra VCC, Oliveira WEA, Lopes TS, et al. Análise da Estrutura de uma Unidade de Saúde da Família sob a Perspectiva da Ambiência. Rev APS[Internet]. 2014[cited 2018 May 10];17(4):423-8. Available from: https://aps. ufjf.emnuvens.com.br/aps/article/view/2046

16. Oliveira MAC, Pereira IC. Atributos essenciais da atenção primária e a estratégia saúde da família. Rev Bras Enferm[Internet]. 2013[cited 2018 May 10];66(Spe):158-64. Available from: http://www.scielo.br/pdf/reben/v66nspe/v66nspea20.pdf

17. Magnago C, Pierantoni CR. Dificuldades e estratégias de enfrentamento referentes à gestão do trabalho na Estratégia Saúde da Família, na perspectiva dos gestores locais: a experiência dos municípios do Rio de Janeiro (RJ) e Duque de Caxias (RJ). Saúde Debate[Internet]. 2015[cited 2018 May 10];39(104):9-17. Available from: http://www.scielo.br/pdf/sdeb/v39n104/0103-1104sdeb-39-104-00009.pdf

18. Carvalho Filha FSS, Nogueira LT, Medina MG. Avaliação do controle de hipertensão e diabetes na Atenção Básica: perspectiva de profissionais e usuários. Saúde Debate[Internet]. 2014[cited 2018 May 10];38(Spec):265-78. Available from: http://www.scielo. br/pdf/sdeb/v38nspe/0103-1104-sdeb-38-spe-0265.pdf

19. Santos L, Torres HC. Educational practices in Diabetes Mellitus: understanding the skills of health professionals. Texto Contexto Enferm[Internet]. 2012[cited 2018 Jan 20];21(3):574-80. Available from: http://www.scielo.br/pdf/tce/v21n3/en_v21n3a12.pdf

20. Diniz IA, Cavalcante RB, Otoni A, Mata LRF. Perception of primary healthcare management nurses on the nursing process. Rev Bras Enferm[Internet]. 2015[cited 2018 May 20];68(2):206-13. Available from: http://www.scielo.br/pdf/reben/v68n2/en_00347167-reben-68-02-0206.pdf

21. Costa JP, Jorge MSB, Vasconcelos MGF, Paula ML, Bezerra IC. Resolubilidade do cuidado na atenção primária: articulação multiprofissional e rede de serviços. Saúde Debate[Internet]. 2014[cited 2018 Jan 20];38(103):733-43. Available from: http:// www.scielo.br/pdf/sdeb/v38n103/0103-1104-sdeb-38-103-0733.pdf

22. Iquize RCC, Theodoro FCET, Carvalho KA, Oliveira MA, Barros JF, Silva AR. Educational practices in diabetic patient and perspective of health professional: a systematic review. J Bras Nefrol[Internet]. 2017[cited 2018 May 20];39(2):196-204. Available from: http:// www.gnresearch.org/doi/10.5935/0101-2800.20170034

23. Salci MA, Meirelles BHS, Silva DMGV. Primary care for diabetes mellitus patients from the perspective of the care model for chronic conditions. Rev Latino-Am Enfermagem[Internet]. 2017[cited 2018 May 20];25. Available from: http://www.scielo.br/pdf/ rlae/v25/0104-1169-rlae-25-e2882.pdf

24. Trindade LL, Pires DEP. Implicações dos modelos assistenciais da atenção básica nas cargas de trabalho dos profissionais de saúde. Texto Contexto Enferm[Internet]. 2013[cited 2018 Jan 15];22(1):36-42. Available from: http://www.scielo.br/pdf/tce/v22n1/pt_05.pdf

25. Dickinson WP, Dickinson LM, Nutting PA, Emsermann CB, Tutt B, Crabtree BF, et al. Practice facilitation to improve diabetes care in primary care: a report from the EPIC randomized clinical trial. Ann Fam Med[Internet]. 2014[cited 2018 Jan 15];12(1):8-16. Available from: http://www.annfammed.org/content/12/1/8

26. Cavalcanti MCS, Mariano RF, Chaves RGR, Cavalcanti VFS, Barbosa WF. A evolução da enfermagem: um recorte histórico, político e cultural. Congr Bras Cons Enferm[Internet]. 2014[cited 2018 Jan 20];10. Available from: http://apps.cofen.gov.br/cbcenf/ sistemainscricoes/arquivosTrabalhos/I53331.E12.T10220.D8AP.pdf

27. Magagnin AB, Aires LCP, Freitas MA, Heidemann ITSB, Maia ARC. The nurse as a political-social being: perspectives of a professional in transformation. Ciênc Cuid Saúde[Internet]. 2018[cited 2018 Jan 20];17(1):1-7. Available from: http://periodicos.uem.br/ojs/ index.php/CiencCuidSaude/article/view/39575 